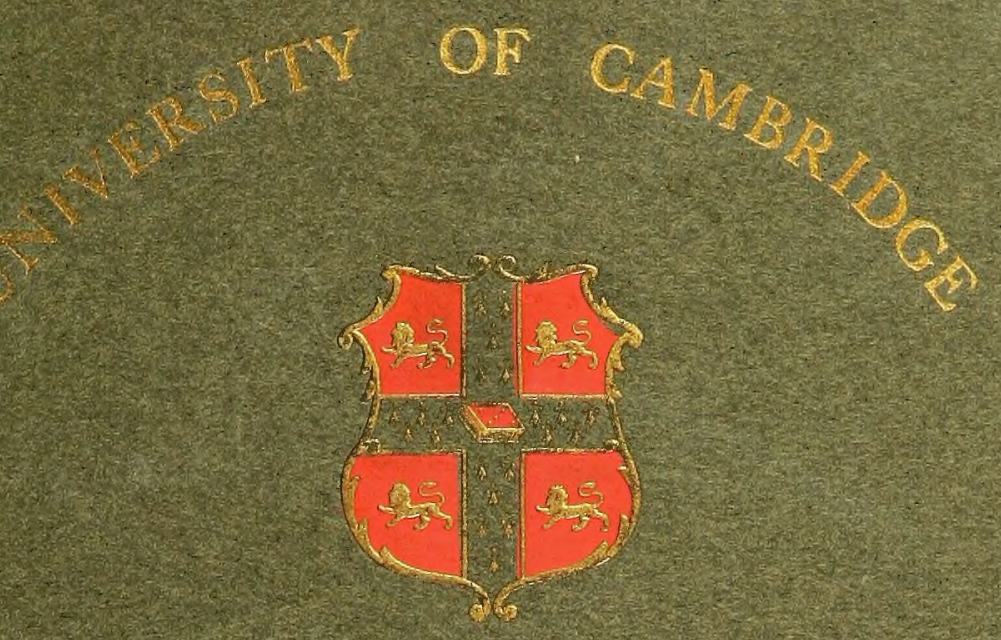

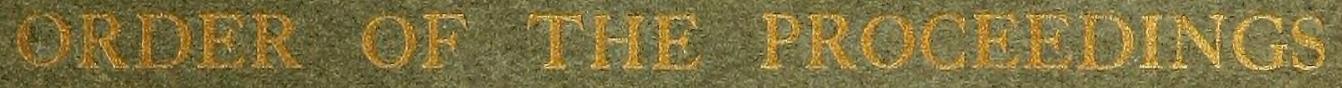
A Th This:

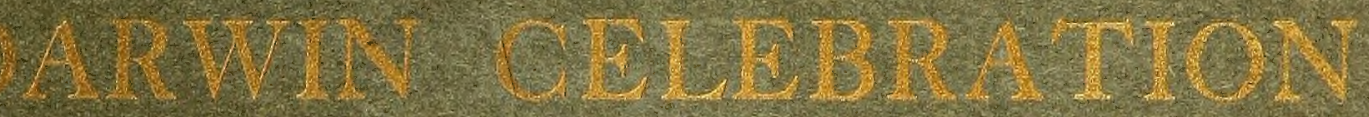

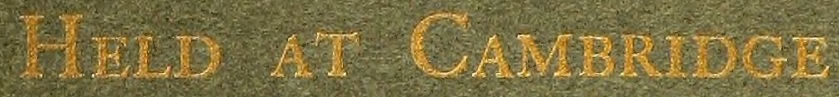

JONB $22-J$ JNB 24

1909

WITH A SKETCH OF DARWINS LIEE 


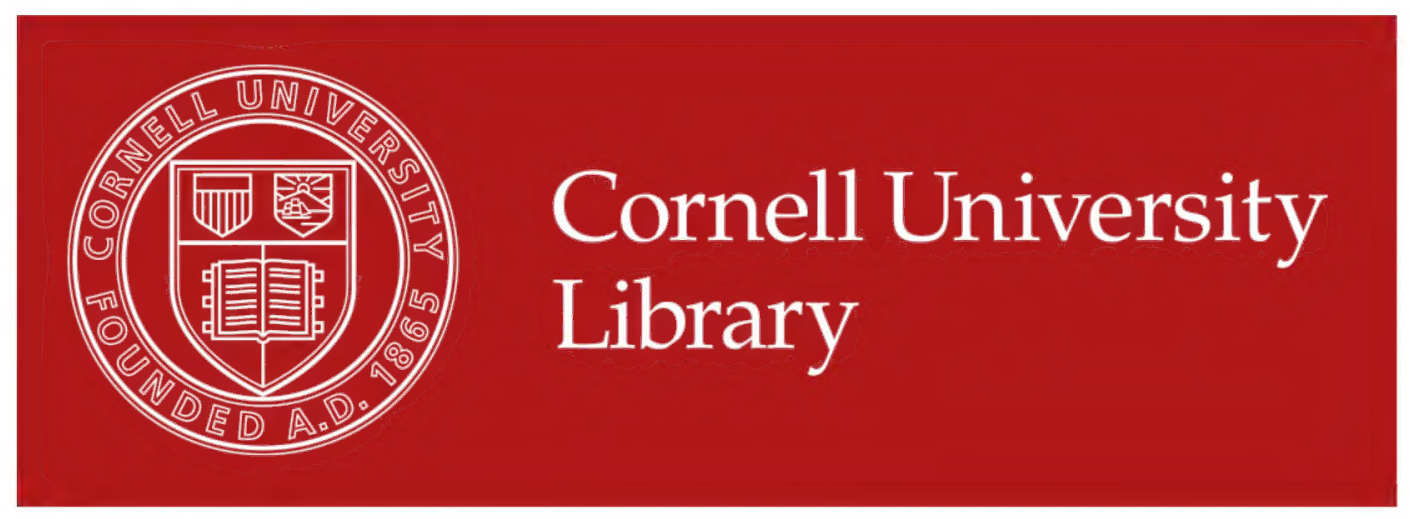

\section{The original of this book is in the Cornell University Library.}

There are no known copyright restrictions in the United States on the use of the text.

http://www.archive.org/details/cu31924024733440 


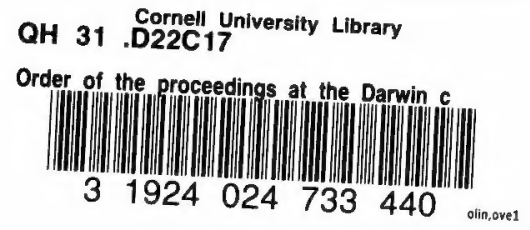





\title{
ORDER OF PROCEEDINGS
}

\author{
AT THE \\ DARWIN CELEBRATION
}






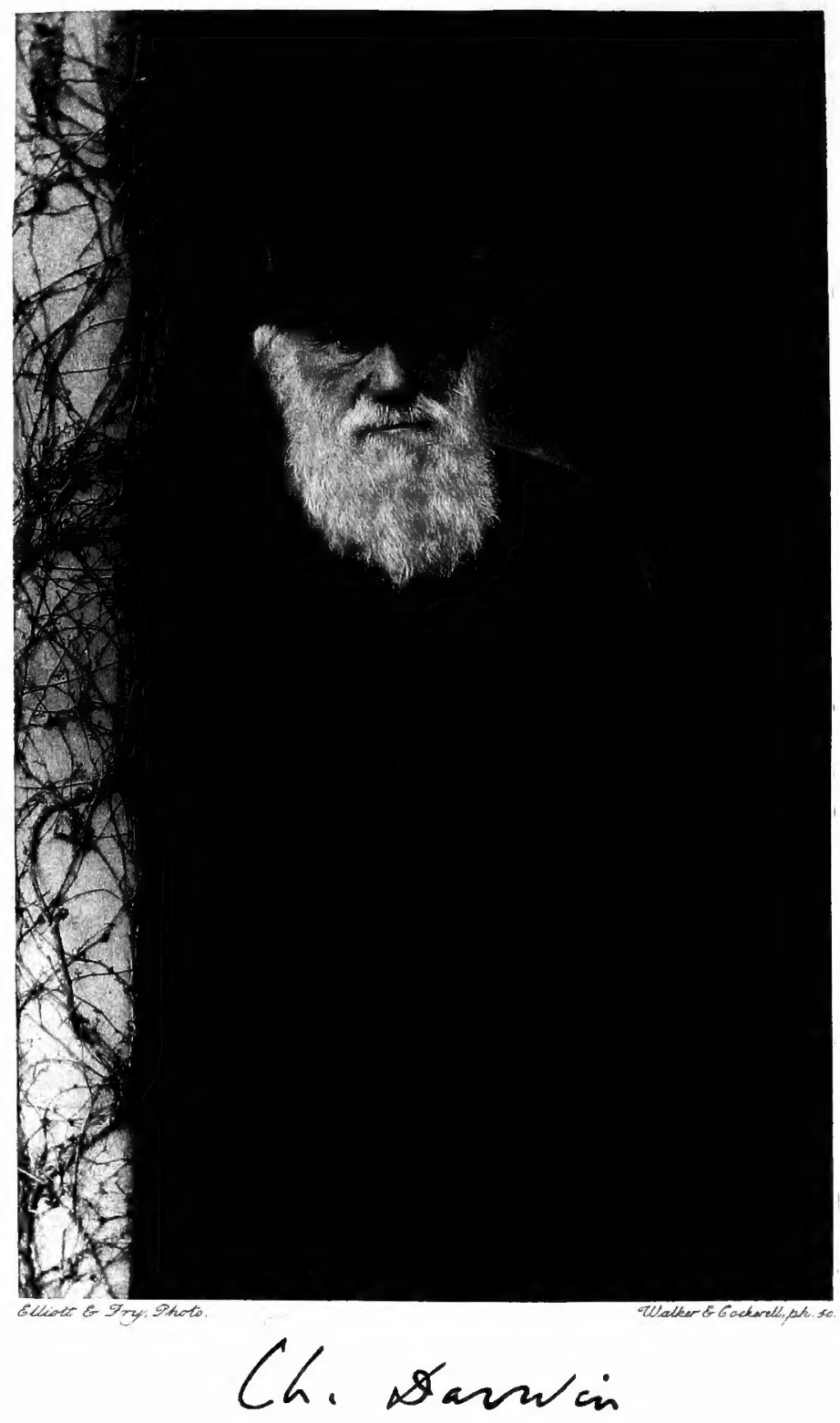




\title{
ORDER OF THE PROCEEDINGS
}

\author{
AT THE
}

\section{DARWIN CELEBRATION}

\author{
Held at Cambridge \\ JUNE 22-JUne 24, \\ I 909
}

WITH A SKETCH OF DARWIN'S LIFE

Cambridge

Printed at the University Press

I 909 



\section{LIST OF PLATES}

Charles Darwin, 188r. (From a photograph by Elliott and Fry) . . Frontispiece Map of Cambridge . . . . . . . . to face Programme

I. The Mount, Shrewsbury. The birthplace of Charles Darwin . . page I3

II. Charles Darwin and his sister Catherine. (From a coloured chalk drazeing

by Sharples, in the possession of Miss Wedgwood of Leith Hill Place) . I3

III. Charles Darwin's rooms in the front court of Christ's College (staircase G) - I4

IV. John Stevens Henslow (1796-186r), Professor of Mineralogy in the University of Cambridge from 1822 to 1828 ; Professor of Botany from 1825 to $186 \mathrm{I}$.

(From a photograph) . . . . . . . . .

V. H.M.S. Beagle in the Straits of Magellan. Mt. Sarmiento in the distance.

(From a block lent by Mr John Murray) . . . . . . 15

VI. Mrs Darwin, ז88I. (From a photograph by Barraud) . . . . . I6

VII. Mr Darwin's house at Down in Kent . . . . . . . . I7

VIII. The Sandwalk at Down (From a photograph by England) . . . . I7

IX. Charles Darwin, I849. (From the Ipswich British Association series) . . I8

X. Joseph Dalton Hooker, I897. (From a photograph by Hawker) . . . I8 



\section{PREFACE}

A $\mathrm{T}$ a meeting of the Council of the Senate held on Monday, December 2, 1907, a Committee was appointed to consider what steps should be taken to celebrate the Centenary of the birth of Charles Darwin. On February I3, 1908, it was agreed by Grace of the Senate to hold a Darwin Celebration in the course of the year 1909, and in the following month the Committee was increased in size and constituted as follows: The ViceChancellor (Rev. E. S. Roberts, Master of Gonville and Caius College), the Master of Pembroke College (Rev. Dr A. J. Mason), the Master of Christ's College (Dr Peile), the Registrary of the University (Mr J. W. Clark), Professor Sir Robert Ball, Professor Bateson, Dr Bonney, Mr Durnford, Dr Fletcher, Professor Forsyth, Dr Gaskell, Professor $M^{\circ}$ Kenny Hughes, Mr A. Hutchinson, Professor Langley, Professor Larmor, Professor Liveing, Dr Marr, Mr Punnett, Professor Sedgwick, Professor Seward, Mr Shipley.

By Grace of the Senate, March 4, I909, it was agreed to contribute the sum of $£_{500}$ from the University Chest towards the expense of the Celebration; and at a subsequent date the Vice-Chancellor (Rev. A. J. Mason, Master of Pembroke College) announced to the Senate that an anonymous benefactor had generously offered to contribute an additional $£ 500$.

In the preparation of the Sketch of Mr Darwin's life, which follows the lines of the Epitome included in the Memorial volume of essays, Darwin and Modern Science, recently published by the Syndics of the University Press, we 
have received considerable assistance from $\mathrm{Mr}$ Francis Darwin, to whom we offer our cordial thanks. The portraits reproduced as the Frontispiece and as Plates II, IV, VI, and X are reproduced from plates originally published in More Letters of Charles Darwin. For the use of these we are indebted to Mr Francis Darwin, and to the courtesy of Mr John Murray. For the loan of Plate $\mathrm{V}$ our thanks are due to Mr John Murray, by whom the illustration was first published in an edition of the Journal of Researches in I89o. Plate III is from a photograph taken by permission of the Master of Christ's College by Messrs Scott and Wilkinson of Cambridge. Plate I is reproduced from a photograph in the possession of Sir George Darwin, and Plates VII, VIII, IX are from originals supplied by Mr Francis Darwin.

$\left.\begin{array}{l}\text { J. W. CLARK } \\ \text { A. C. SEWARD }\end{array}\right\} \begin{gathered}\text { Honorary Secretaries, } \\ \text { Darwin Celebration Committee. }\end{gathered}$

Cambridge, June, 1909. 



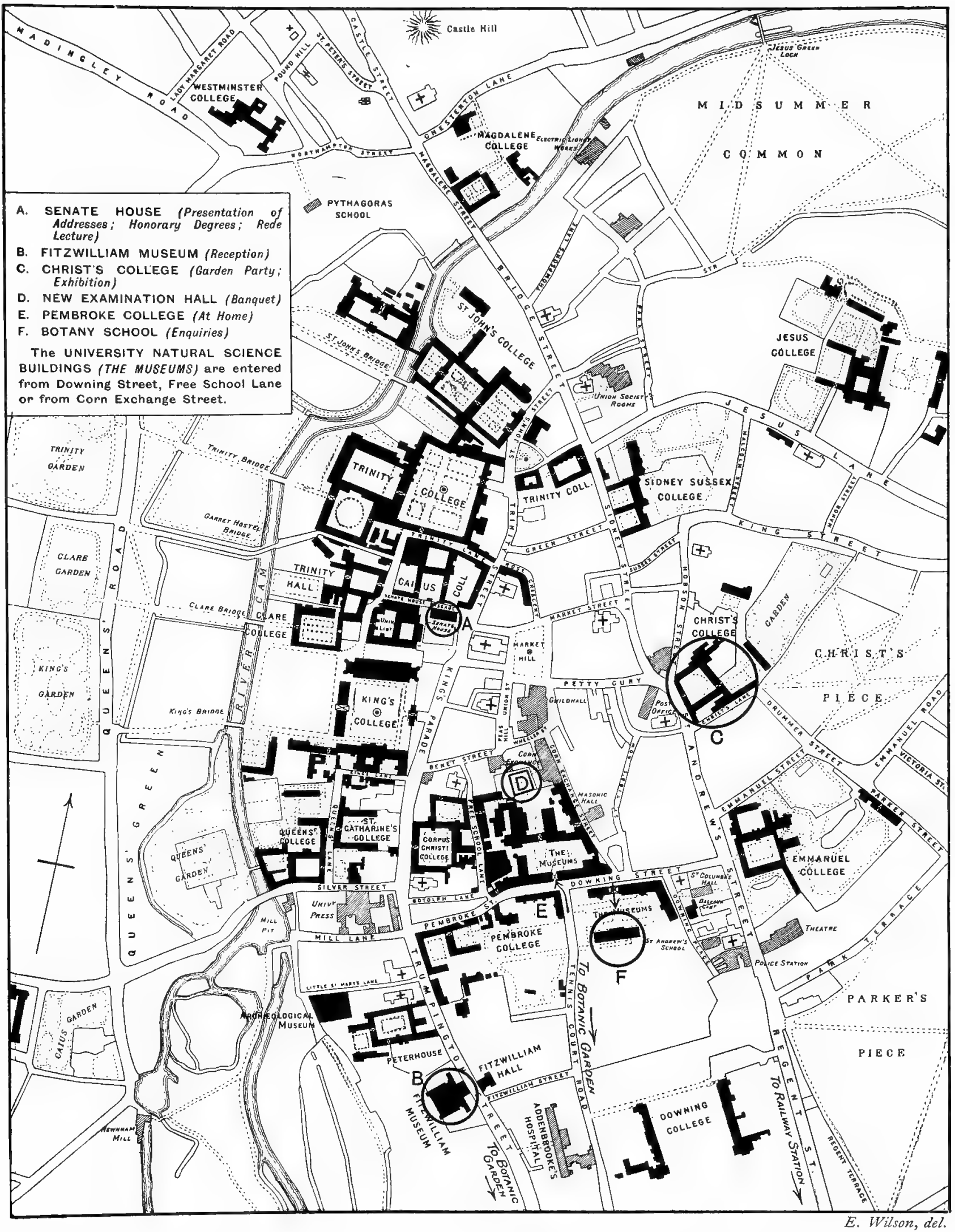

Map of Cambridge 


\title{
UNIVERSITY OF CAMBRIDGE
}

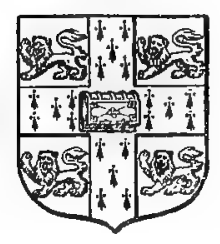

\section{DARWIN COMMEMORATION}

\author{
June 22-24, I909
}

\section{PROGRAMME}

\section{TUESDAY, JUNE 22}

8.30 to II p.m. Reception of Delegates and other invited Guests by the Chancellor of the University (Lord Rayleigh, O.M., F.R.S., Sc.D.) in the Fitzwilliam Museum.

By the kind permission of the Master and Fellows of Peterhouse the College Gardens will be accessible from the Museum.

[Evening dress, Academic robes, and Orders will be worn. (Members of the Senate will wear Hoods and Bands and Doctors will wear Scarlet.)

L'habit sera de rigueur (pour les Universitaires costume Académique) et décorations.

Frack, Akademischer Ornat, und Orden.]

It is very important that invitation cards should be shown at the entrance to the Museum.

Delegates and other Guests who are not Resident Members of the Senate will be received by the Chancellor at the head of the Staircase. After being received Guests are requested to pass on into the Picture Galleries. The entrance to the Refreshment marquee and to the Grounds of Peterhouse is from the First Egyptian room on the ground-floor.

In order to avoid confusion in calling carriages after the Reception, Guests are requested to see that on alighting from their carriages on arrival at the Fitzwilliam Museum they receive a numbered ticket from the Policeman on duty. 


\section{WEDNESDAY, JUNE 23}

ro.30 a.m. Presentation of Addresses by Delegates of Universities, Colleges, Academies, and Learned Societies in the Senate House.

[Morning dress and Academic robes. (Members of the Senate will wear Hoods and Bands and Doctors will wear Scarlet.)

Costume de ville et costume Académique.

Gehrock und Akademischer Ornat.]

(i) Address by the Chancellor.

(ii) Presentation of Delegates and Addresses.

(iii) A few short speeches will be delivered.

2.30 to 3.45. Visits to Colleges.

4 to 6 p.m. Garden Party given by the Master and Fellows of Christ's College in the College grounds.

[Morning dress and Academic robes. (Members of the Senate will wear Hoods and Bands and Doctors will wear Scarlet.)

Costume de ville et costume Académique.

Gehrock und Akademischer Ornat.]

The rooms occupied by Charles Darwin when an Undergraduate of Christ's College (First Court, Staircase G) will be open to Visitors during the afternoon of Wednesday, June 23, and during the morning and afternoon of Thursday, June 24.

7 p.m. Banquet in the New Examination Hall, the Museums.

[Evening dress, Academic robes, and Orders.

L'habit sera de rigueur (pour les Universitaires costume Académique) et décorations.

Frack, Akademischer Ornat, und Orden.]

[Entrance from Pembroke Street. Carriages should be ordered to set down Guests at the entrance to the Museums, Pembroke Street, and to take up Guests after the Pembroke College At Home at the College Gateway, Trumpington Street.

Guests are requested to assemble at the New Examination Hall at 6.45 p.m.]

Io to I2 p.m. The Master and Fellows of Pembroke College At Home in the College Hall and Gardens.

[Entrance to Pembroke College from Trumpington Street.

Guests attending the Banquet can enter the College by the Gate in Pembroke Street.] 


\section{THURSDAY, JUNE 24}

II a.m. Honorary Degrees conferred in the Senate House.

I2 noon. Rede Lecture delivered by Sir Archibald Geikie, Sc.D., President of the Royal Society of London: Subject, Darwin as Geologist.

[Morning dress and Academic robes. (Members of the Senate will wear Hoods and Bands and Doctors will wear Scarlet.)

Costume de ville et costume Académique.

Gehrock und Academischer Ornat.]

3 to 5.30 p.m. Garden Party given by $\mathrm{Mr}$ William Erasmus Darwin, Sir George and Lady Darwin, $\mathrm{Mr}$ Francis Darwin and Miss Frances Darwin, Major and Mrs Leonard Darwin, Mr and Mrs Horace Darwin, Mrs Litchfield, and Miss Darwin, in the Fellows' Garden, or, if wet, in the Hall and Cloisters of Trinity College, which have been kindly lent by the Master and Fellows.

[Morning dress.

Costume de ville.

Gehrock.]

(Entrance to the Garden from the Backs of the Colleges.)

\section{Darwin Exhibition}

During the Celebration there will be an Exhibition of portraits, books, and other objects of interest in connexion with Darwin, in the Old Library of Christ's College (Entrance from the First Court). The Exhibition will be open from Io a.m. to I p.m. and from 2 p.m. to 5 p.m.

(Catalogues may be bought in the Exhibition Room.)

\section{Charles Darwin's Library}

This Library, which $\mathrm{Mr}$ Francis Darwin has generously transferred to the Botany School, Downing Street, may be seen on application at the Botany School at any time between Io a.m. and I p.m., or between 2.30 p.m. and 5.30 p.m., during the Celebration. A few of the most interesting volumes will be displayed in the Botanical Museum. 


\section{Geological Collection}

The rock-specimens collected by Darwin during the voyage of the Beagle are exhibited in the Sedgwick Museum, Downing Street.

\section{University Library}

The Librarian has arranged an Exhibition of MSS. and Books illustrating the progress of Scientific Study.

\section{Enquiries}

Enquiries should be addressed to the Honorary Secretaries, Darwin Celebration, The Botany School.

Professor Seward will be in his room at the Botany School, Downing Street, on Tuesday, June 22, between 2.30 and 5.30 .

J. W. CLARK, M.A. Honorary Secretaries, A. C. SEWARD, M.A. $\}$ Darwin Celebration.

June, 1909. 

Plate 1

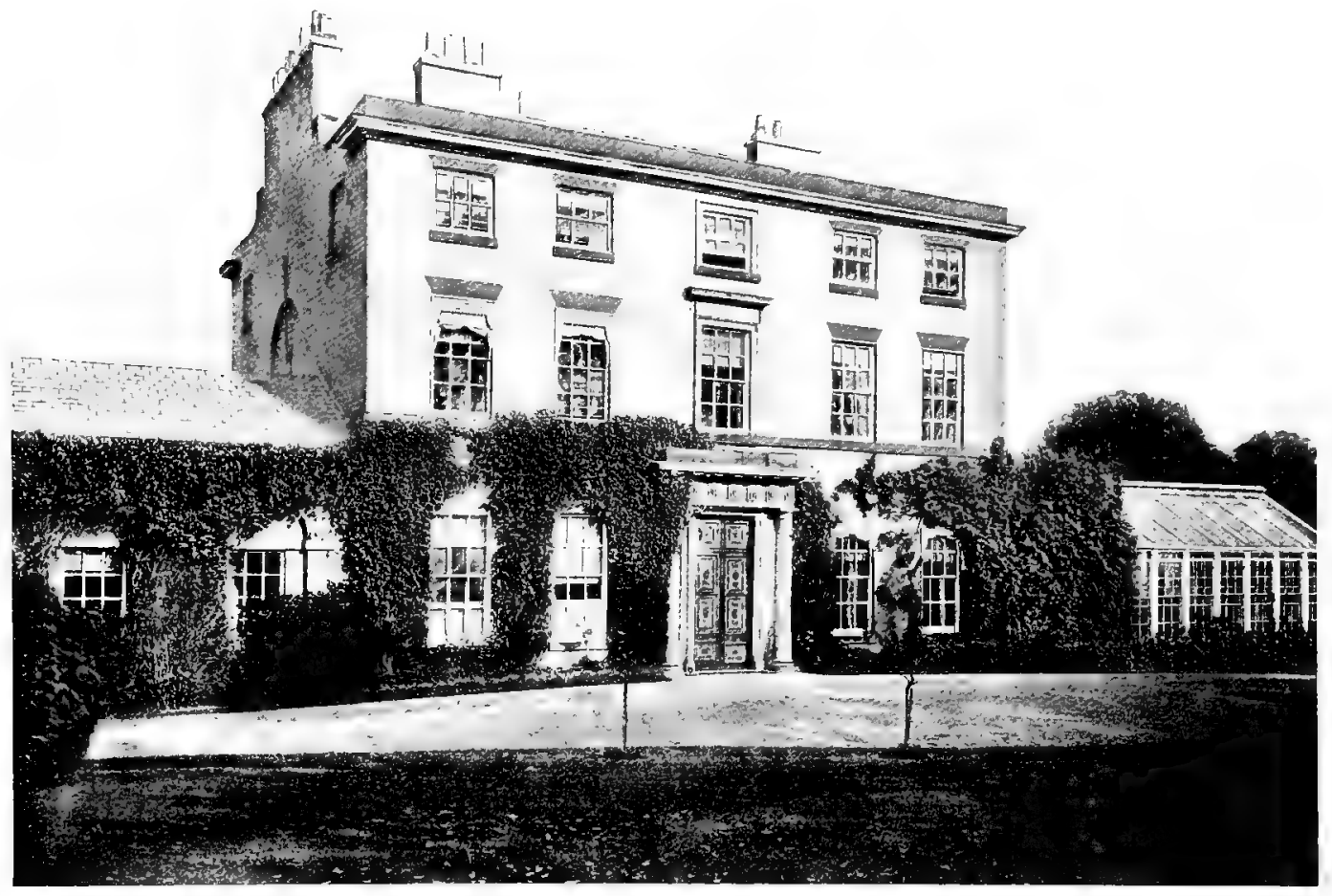

The Mount, Shrewsbury 

Plate II

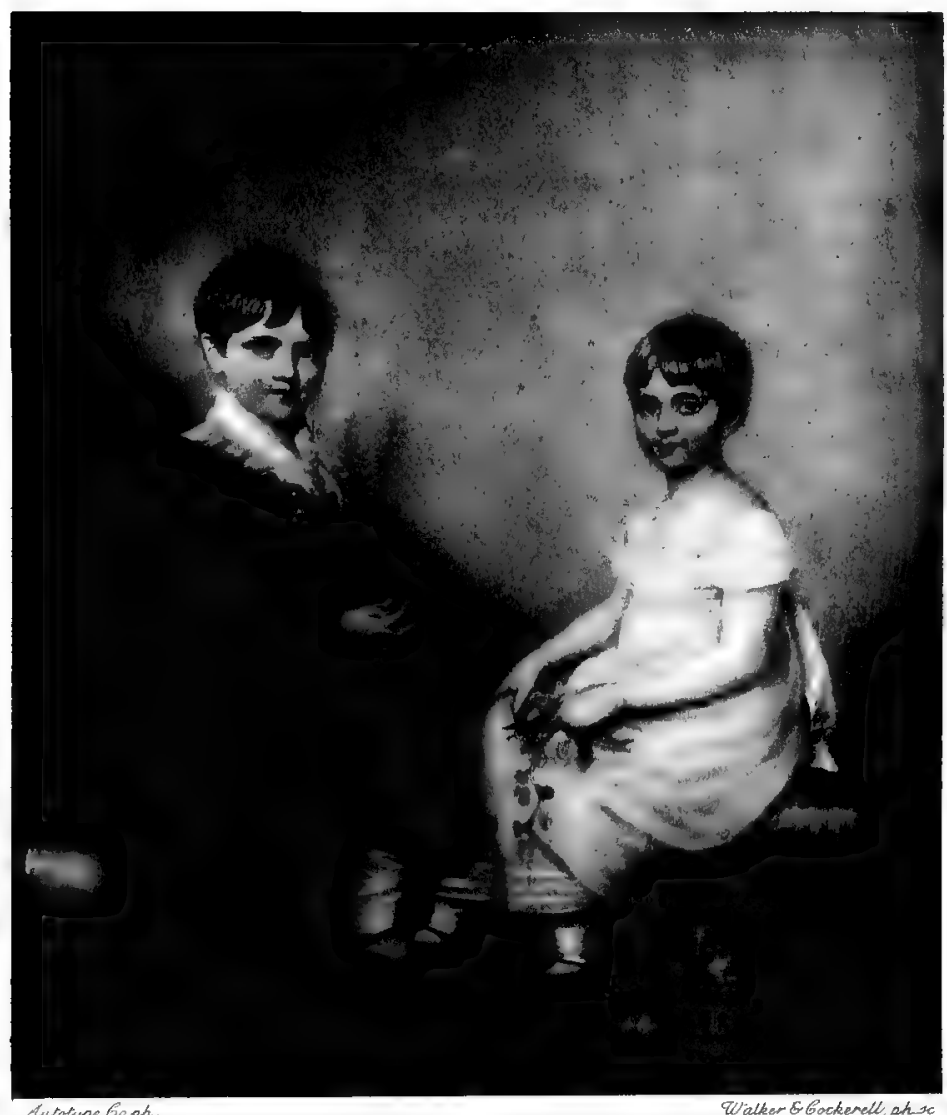

Tharles Darwin \& his sister batherine

Trem ex shath dravingin the prossession of - Hisa Whedquoed of Peith Hill Shace 


\section{A SKETCH OF DARWIN'S LIFE'}

I809 Charles Robert Darwin, born Feb. 12, at The Mount, Shrewsbury (Plate I), the house of his father, Dr Robert Waring Darwin (b. 1766, d. I 848), who was the son of Erasmus Darwin (b. I73I, d. I802), Poet, Physician and Evolutionist. On the mother's side Charles Darwin was grandson of Josiah Wedgwood (b. 1730, d. I795), the founder of the Etruria Pottery Works, Staffordshire.

Charles Darwin retained a strong feeling of love and respect for his father's memory. His recollection of everything connected with him was peculiarly distinct, and he spoke of him frequently, generally prefacing an anecdote with some such phrase as "My father, who was the wisest man I ever knew."

"He was about 6 feet 2 inches in height, with broad shoulders, and very corpulent, so that he was the largest man whom I ever saw.... His chief mental characteristics were his powers of observation and his sympathy, neither of which have I ever seen exceeded or even equalled." Darwin's Autobiography.

The house is charmingly placed on a steep bank above the Severn. The terraced bank is traversed by a long walk leading from end to end, still called "The Doctor's Walk." At one point in this walk grows a Spanish chestnut, the branches of which bend back parallel to themselves in a curious manner, and this was Darwin's favourite tree as a boy where he and his sister Catherine (Plate II) had each their special seat.

I8I7 "At 81 years old I went to Mr Case's school." [A day-school at Shrewsbury kept by the Rev. G. Case, Minister of the Unitarian Chapel.] "By the time I went to this day-school my taste for natural history, and more especially for collecting, was well developed. I tried to make out the names of plants, and collected all sorts of things, shells, seals, franks, coins, and

1 The quotations are taken for the most part from Charles Darwin's Autobiography (Life and Letters of Charles Darwin, Vol. I, Chapters I and II), from the Pocket Diary, and from letters published in the Life and Letters or in More Letters of Charles Danwin. 
minerals. The passion for collecting which leads a man to be a systematic naturalist, a virtuoso, or a miser, was very strong in me, and was clearly innate, as none of my sisters or brother ever had this taste."

1818

"I was at school at Shrewsbury under a great scholar, Dr Butler; I learnt absolutely nothing, except by amusing myself by reading and experimenting in Chemistry."

I825 "As I was doing no good at school, my father wisely took me away at a rather earlier age than usual, and sent me (Oct. I825) to Edinburgh University with my brother, where I stayed for two years."

1828 "As it was decided that I should be a clergyman, it was necessary that I should go to one of the English Universities and take a degree."

Began residence at Christ's College, Cambridge, in the Lent term. "Carolus Darwin admissus est pensionarius minor sub Mro Shaw." (Christ's College Admission Book.)

Christ's College was founded in I505 by the Lady Margaret Beaufort, mother of Henry VII. Darwin's rooms are on the south side of the first court (Staircase G), above and to the right of the doorway shown in the illustration (Plate III).

"During the three years which I spent at Cambridge my time was wasted, as far as the academical studies were concerned, as completely as at Edinburgh and at school."

"In order to pass the B.A. Examination, it was...necessary to get up Paley's 'Evidences of Christianity,' and his 'Moral Philosophy.'... The careful study of these works, without attempting to learn any part by rote, was the only part of the academical course which... was of the least use to me in the education of my mind."

"I have not as yet mentioned a circumstance which influenced my whole career more than any other. This was my friendship with Professor Henslow (Plate IV).... He kept open house once every week when all undergraduates and some older members of the University, who were attached to science, used to meet in the evening.... Before long I became well acquainted with Henslow, and during the latter half of my time at Cambridge took long walks with him on most days; so that I was called by some of the dons "the man who walks with Henslow."

"As time passed on at Cambridge I became very intimate with Professor Henslow, and his kindness was unbounded; he continually asked me to his house, and allowed me to accompany him in his walks. He talked on all subjects, including his deep sense of religion, and was entirely open. I owe 


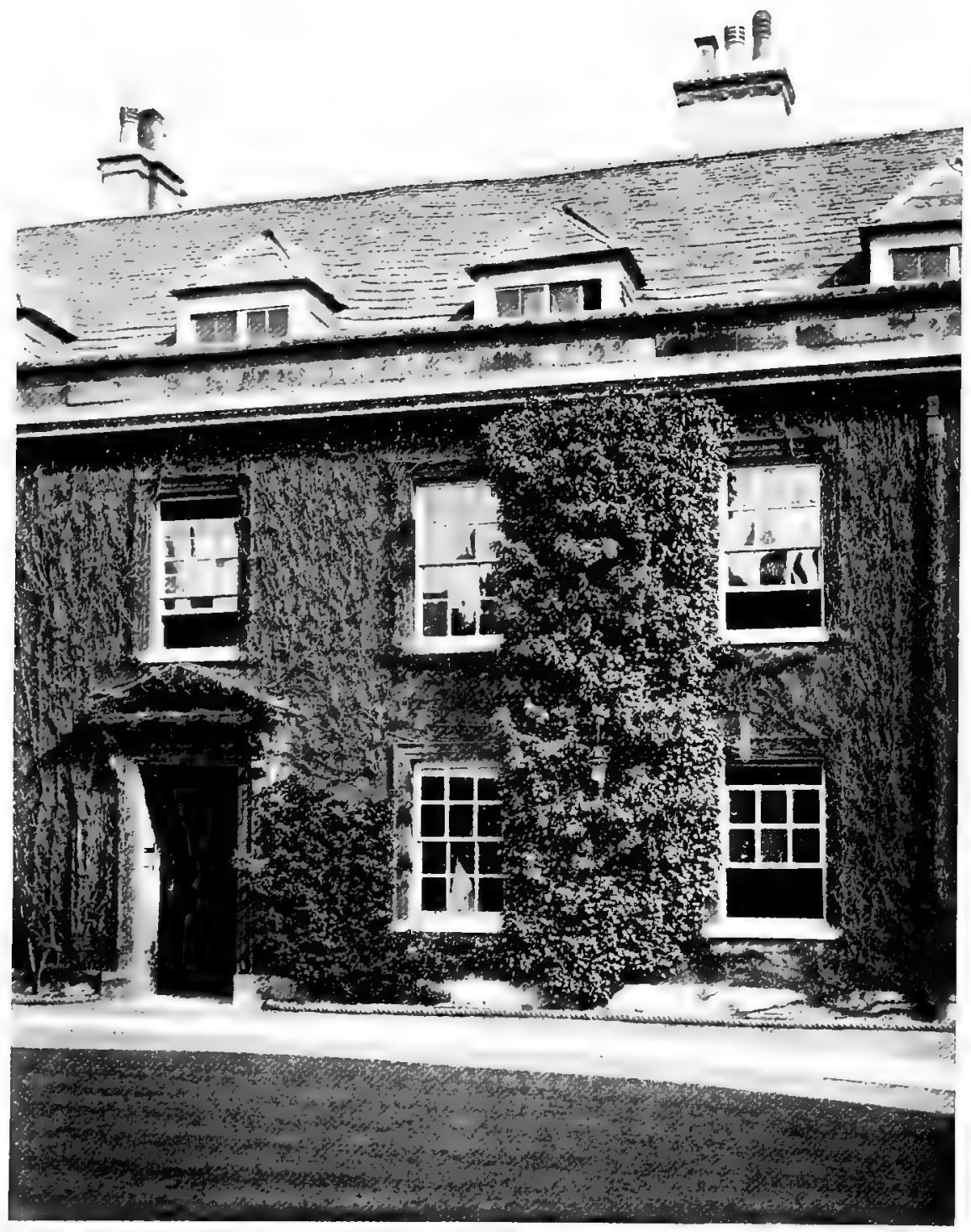

Scott \& Wilkinson, phot.

Mr Darwin's rooms in Christ's College

(Front Court, Staircase G, First floor) 



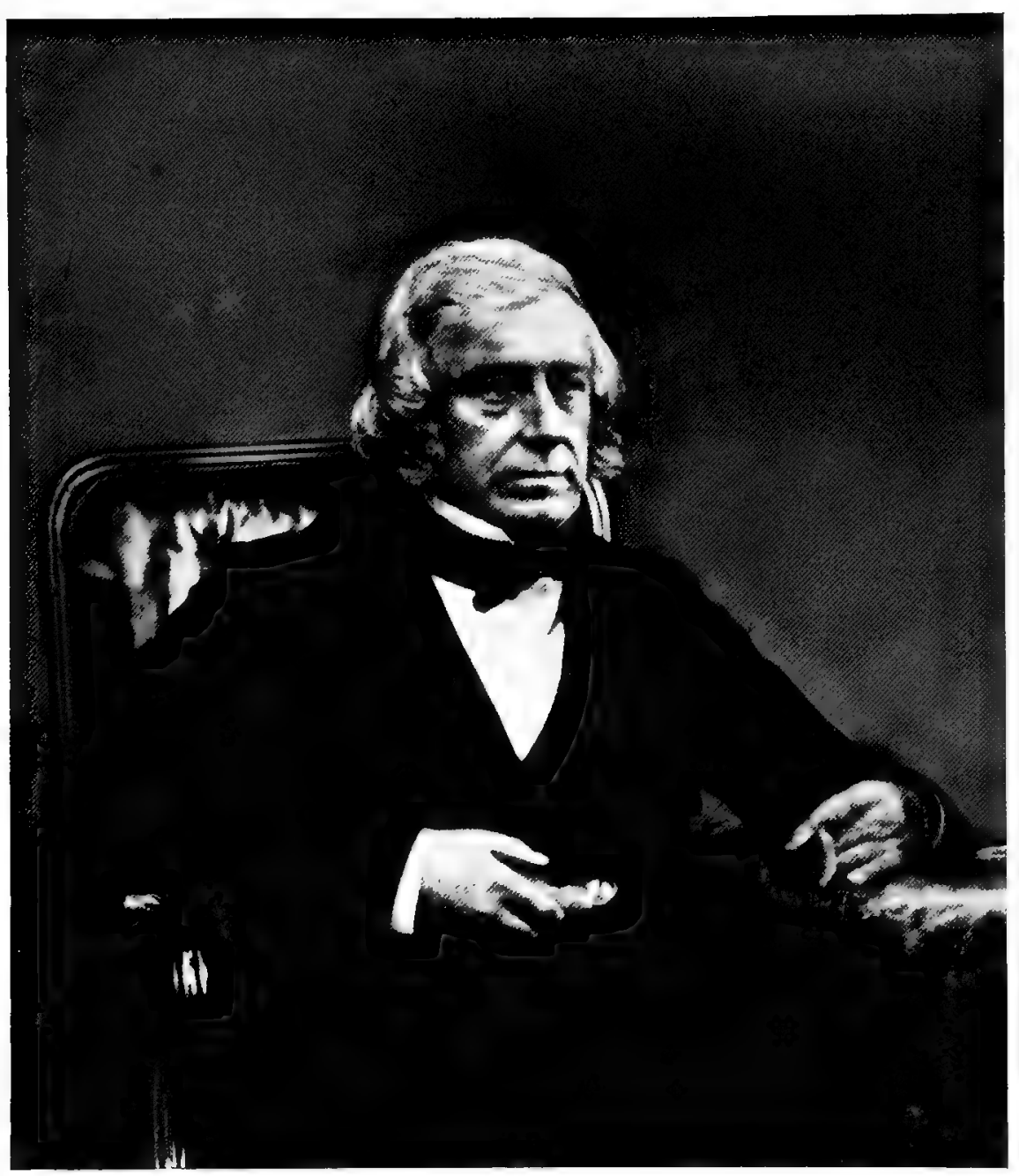

John Stevens Henslow 



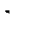


Ilate $V$

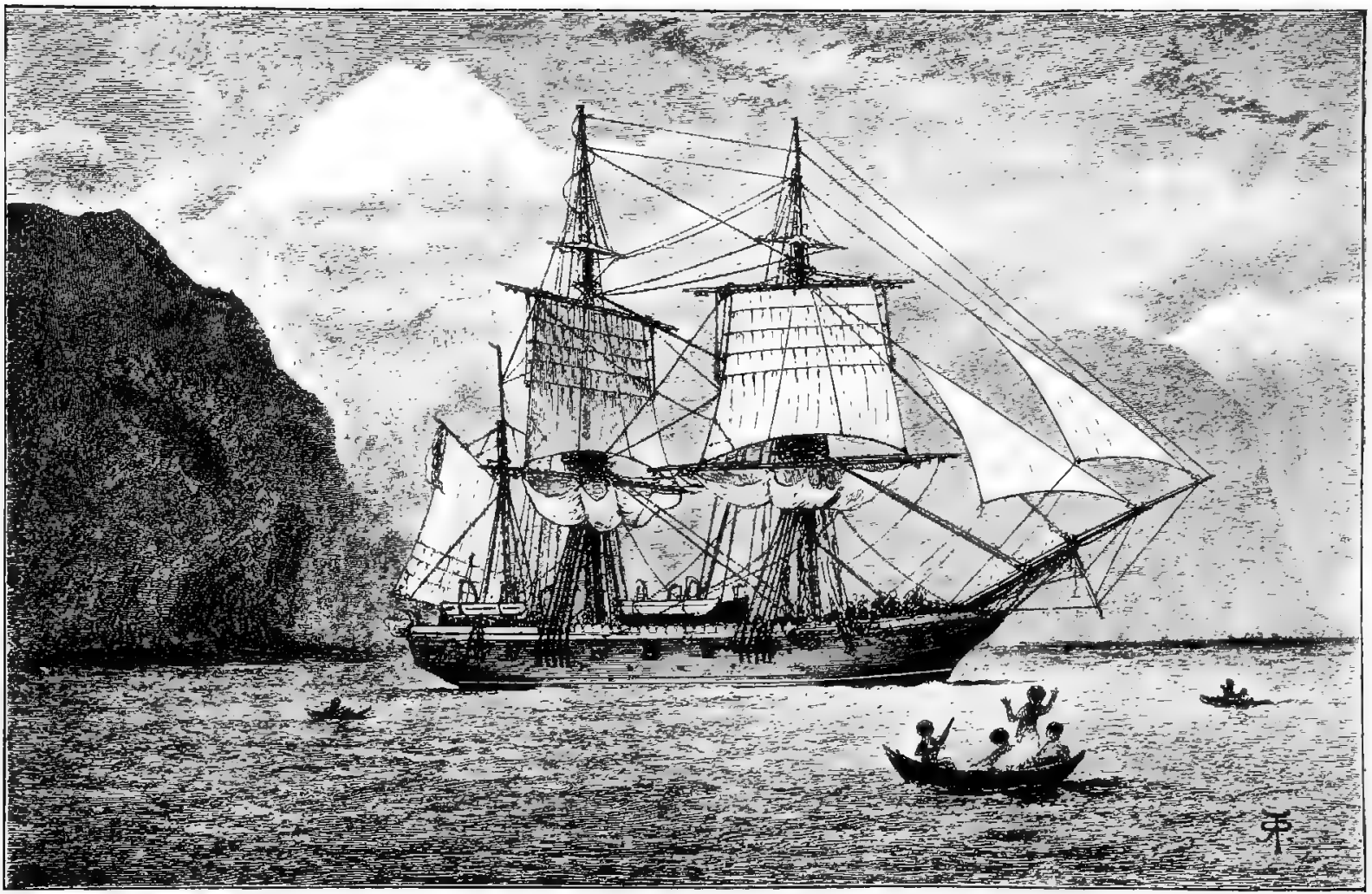

H.M.S. "Beagle" in the Straits of Magellan 
more than I can express to this excellent man. His kindness was steady: when Captain FitzRoy offered to give up part of his own cabin to any naturalist who would join the expedition in H.M.S. Beagle, Professor Henslow recommended me, as one who knew very little, but who, he thought, would work. I was strongly attached to natural history, and this attachment I owed, in large part, to him." C. Darwin in L. Jenyns' Memoir of Henslow, I 862.

183I Passed the examination for the B.A. degree in January and kept the two following terms.

"On returning home [August] from my short geological tour in North Wales [with Professor Sedgwick], I found a letter from Henslow, informing me that Captain FitzRoy was willing to give up part of his own cabin to any young man who would volunteer to go with him without pay as naturalist to the voyage of the Beagle."

Dec. 27. "Sailed from England on our circumnavigation" in H.M.S. Beagle, a barque of 235 tons, carrying 6 guns, under Captain FitzRoy (Plate V).

"It shall be as a birthday for the rest of my life."

"The voyage of the Beagle has been by far the most important event in my life, and has determined my whole career."

"Everything about which I thought or read was made to bear directly on what I had seen or was likely to see; and this habit of mind was continued during the five years of the voyage. I feel sure that it was this training which has enabled me to do whatever I have done in science."

I836 Oct. 4. "Reached Shrewsbury after absence of 5 years and 2 days." "You cannot imagine how gloriously delightful my first visit was at home; it was worth the banishment."

Dec. I3. Went to live at Cambridge (Fitzwilliam Street).

1837 "On my return home [in the Beagle] in the autumn of 1836 I immediately began to prepare my journal for publication, and then ${ }^{1}$ saw how many facts indicated the common descent of species.... In July (1837) I opened my first note-book for facts in relation to the origin of species, about which I had long reflected, and never ceased working for the next twenty years. ... Had been greatly struck from about month of previous March on character of South American fossils, and species on Galapagos Archipelago. These facts origin (especially latter) of all my views."

'On the question of when Darwin's mind was first turned towards Evolution, see Professor Judd in Darwin and Modern Science (Cambridge, I9०9), also the introduction to The Foundations of the Origin of Species. 
"On March 7, 1837, I took lodgings in [36] Great Marlborough Street in London, and remained there for nearly two years, until I was married."

I838 "In October 1838 , that is, fifteen months after I had begun my systematic enquiry, I happened to read for amusement 'Malthus on Population,' and being well prepared to appreciate the struggle for existence which everywhere goes on from long-continued observation of the habits of animals and plants, it at once struck me that under these circumstances favourable variations would tend to be preserved, and unfavourable ones to be destroyed. The result of this would be the formation of new species. Here then I had at last got a theory by which to work; but I was so anxious to avoid prejudice, that I determined not for some time to write even the briefest sketch of it."

I839 Married at Maer (Staffordshire) to his cousin, Emma Wedgwood, b. 1808 , d. I 896 , daughter of Josiah Wedgwood. (Plate VI.)

Dec. 31. "Entered I 2 Upper Gower Street" [now i Io Gower Street, London].

"If the character of my father's working life is to be understood, the conditions of ill-health, under which he worked, must be constantly borne in mind.... No one indeed, except my mother, knows the full amount of suffering he endured, or the full amount of his wonderful patience. For all the latter years of his life she never left him for a night; and her days were so planned that all his resting hours might be shared with her. She shielded him from every avoidable annoyance, and omitted nothing that might save him trouble, or prevent him becoming overtired, or that might alleviate the many discomforts of his ill-health. I hesitate to speak thus freely of a thing so sacred as the life-long devotion which prompted all this constant and tender care. But it is, I repeat, a principal feature of his life, that for nearly forty years he never knew one day of the health of ordinary men, and that thus his life was one long struggle against the weariness and strain of sickness. And this cannot be told without speaking of the one condition which enabled him to bear the strain and fight out the struggle to the end." Francis Darwin in The Life and Letters.

Published Journal and Researches, being Vol. III. of the Narrative of the Surveying Voyage of H.M.S. Adventure and Beagle....

1842 "In June 1842 I first allowed myself the satisfaction of writing a very brief abstract of my [species] theory in pencil in 35 pages $^{1}$; and this was

1 This MS, published under the title The Foundations of the Origin of Species, will be presented by the Syndics of the University Press to the Delegates attending the Celebration. 
Plate VI

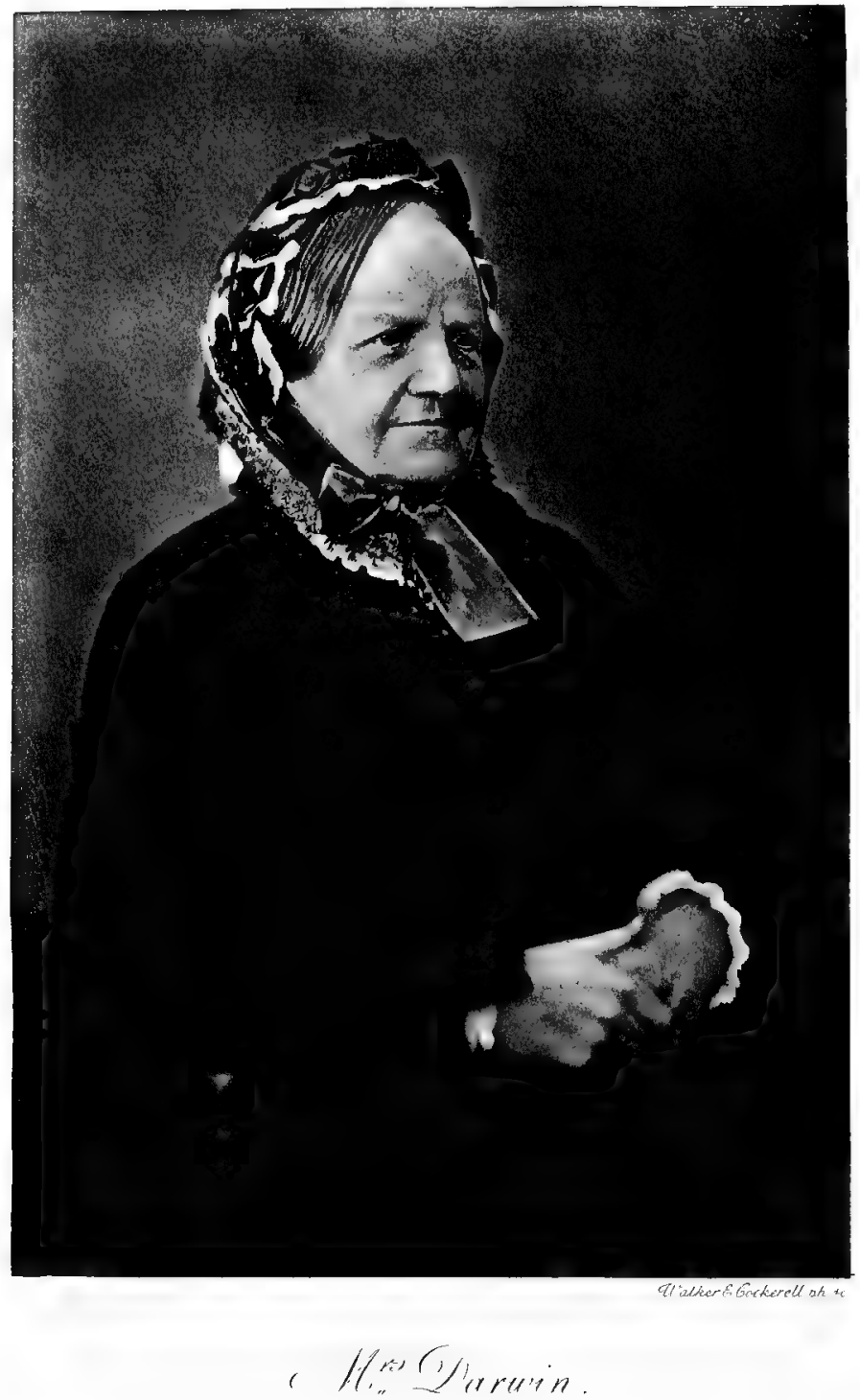




Plate $V I I$

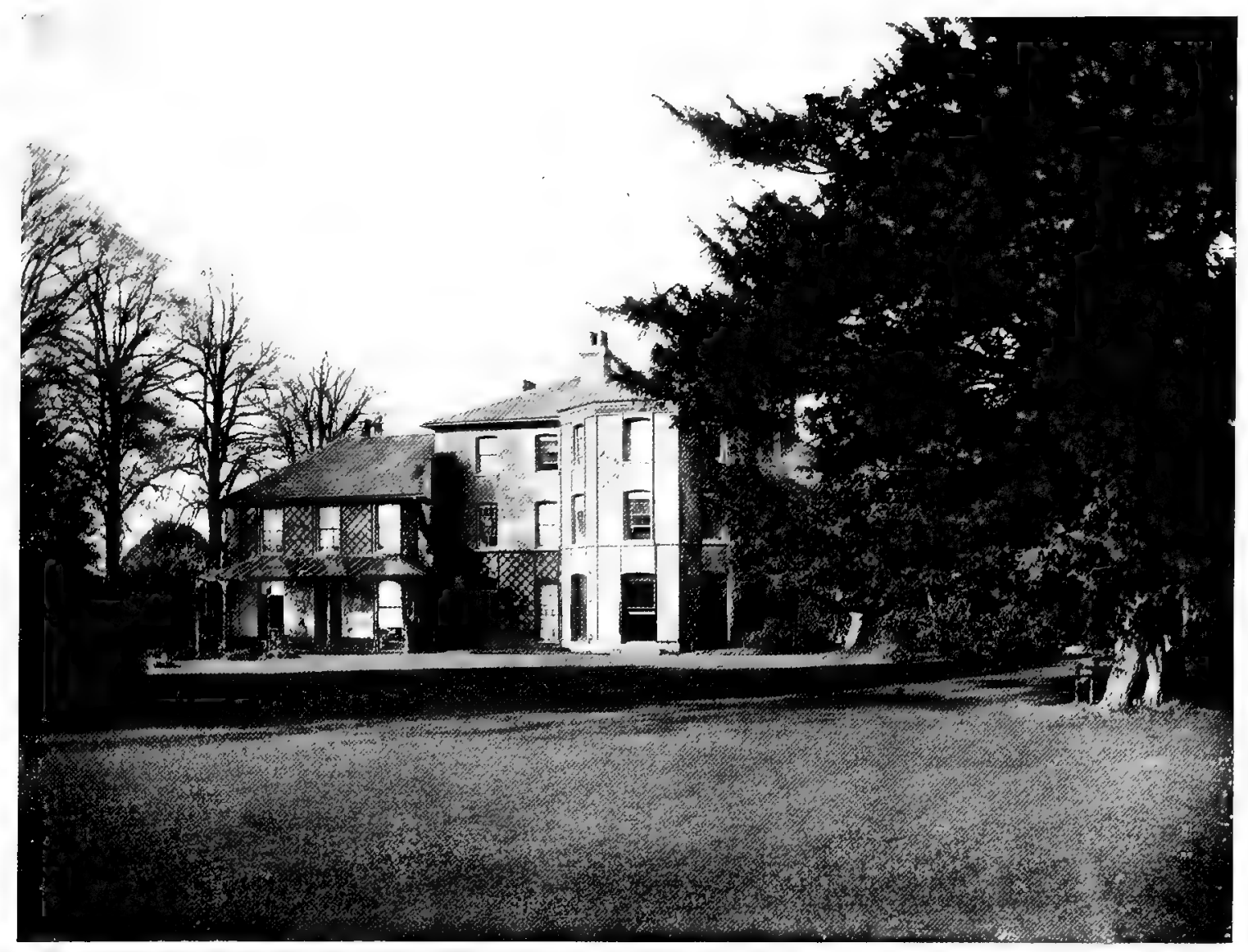

Mr Darwin's House at Down 

Plate VIII

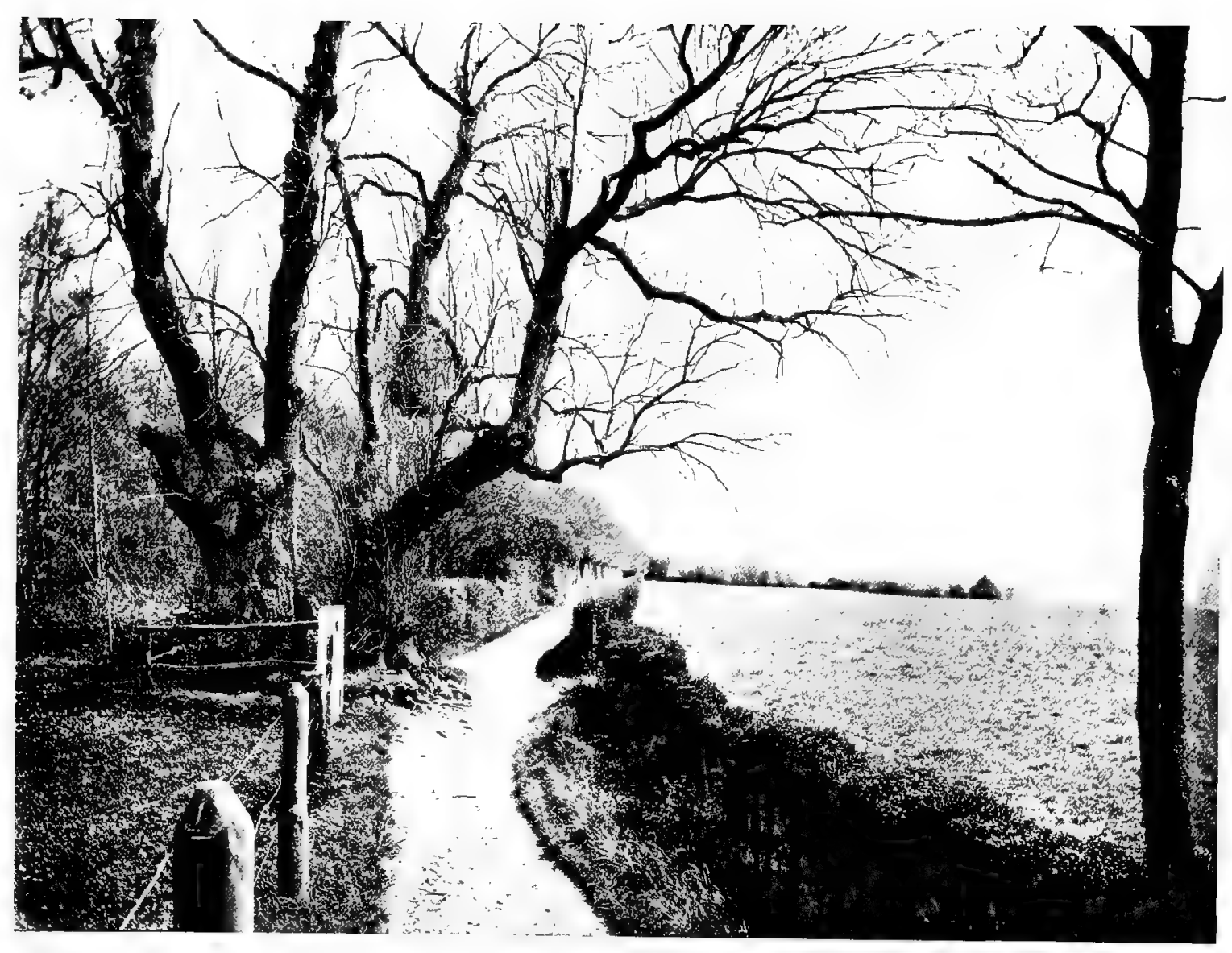

The Sandwalk at Down 
enlarged during the summer of I 844 into one of 230 pages, which I had fairly copied out and still [1876] possess."."

Sept. 14. Settled at the village of Down in Kent. (Plate VII.) "My life goes on like clockwork, and I am fixed on the spot where I shall end it."

Darwin's house lies i 8 miles from London, close to the village of Down, which stands in a solitary upland country, 500 or 600 feet above sea-level, - a country with little natural beauty, but possessing a certain charm in the shaws, or straggling strips of wood, capping the chalky banks and looking down upon the quiet ploughed lands of the valleys. The village, of a few hundred inhabitants, consists of three little streets of cottages meeting by the flint-built church. It is a place where new-comers are seldom seen, and where the names occurring in the old church registers are still borne by the villagers.

"Its chief merit is its extreme rurality. I think I was never in a more perfectly quiet country." (I 843.)

The Sandwalk (Plate VIII) was planted by my father with a variety of trees, such as hazel, alder, lime, hornbeam, birch, privet, and dogwood, and with a long line of hollies all down the exposed side. Here he took a certain number of turns every day, and used to count them by means of a heap of flints, one of which he kicked aside each time he passed. The Sandwalk was our play-ground as children, and here we continually saw my father as he walked round. He liked to see what we were doing, and was ever ready to sympathise in any fun that was going on. With regard to the Sandwalk, in connection with our father, his children's earliest recollections coincide with their latest, - so unchanging were his habits.

Adapted from Francis Darwin's Reminiscences in Life and Letters.

Publication of The Structure and Distribution of Coral Reefs; being Part I. of the Geology of the Voyage of the Beagle.

"I wish that some doubly rich millionaire would take it into his head to have borings made in some of the Pacific and Indian atolls, and bring home cores for slicing from a depth of 500 or 600 feet." C. Darwin, i $88 \mathrm{I}$.

"Though the 'doubly rich millionaire' has not been forthcoming, the energy, in England, of Professor Sollas, and in New South Wales of Professor Anderson Stuart, served to set on foot a project, which, aided at first by the British Association for the Advancement of Science, and afterwards taken up jointly by the Royal Society, the New South Wales Government, and the Admiralty, has led to the most definite and conclusive

${ }^{1}$ A Volume containing both these Essays will be published by the Cambridge University Press in June of this year. 
results... The verdict arrived at, after this most exhaustive study of a series of cores obtained from depths twice as great as that thought necessary by Darwin was as follows:-

"The whole of the cores are found to be built up of those organisms which are seen forming coral-reefs near the surface of the ocean-many of them evidently, in situ; and not the slightest indication could be detected, by chemical or microscopic means, which suggested the proximity of noncalcareous rocks, even in the lowest portions brought up."

\section{J. W. Judd in Darwin and Modern Science.}

"I am very full of Darwin's new theory of Coral Islands, and have urged Whewell to make him read it at our next meeting. I must give up my volcanic crater theory for ever, though it cost me a pang at first, for it accounted for so much.... Yet spite of all this, the whole theory is knocked on the head." Lyell, I 837 .

"I never forget that almost everything which I have done in science I owe to the study of his [Sir Charles Lyell's] great works."

1844 Publication of Geological Observations on the Volcanic Islands visited during the Voyage of H.M.S. Beagle; being Part II. of the Geology of the Voyage of the Beagle.

I845 Publication of the Journal of Researches as a separate book.

I846 Publication of Geological Observations on South America; being Part III. of the Geologv of the Voyage of the Beagle.

185I Publication of a Monograph of the Fossil Lepadida and of a Monograph of the sub-class Cirripedia (Barnacles).

I853 Received one of the two Royal medals which are awarded by the Sovereign upon the recommendation of the Council of the Royal Society.

"Amongst my letters received this morning, I opened first one from Colonel Sabine [Treasurer of the Royal Society]; the contents certainly surprised me very much, but, though the letter was a very kind one, somehow, I cared very little indeed for the announcement it contained. I then opened yours, and such is the effect of warmth, friendship, and kindness from one that is loved, that the very same fact, told as you told it, made me glow with pleasure till my very heart throbbed. Believe me, I shall not soon forget the pleasure of your letter. Such hearty, affectionate sympathy is worth more than all the medals that ever were or will be coined." Letter to Hooker, i 853. (Plate X.)

I854 Publication of Monographs of the Balanidae and Verrucidae. 


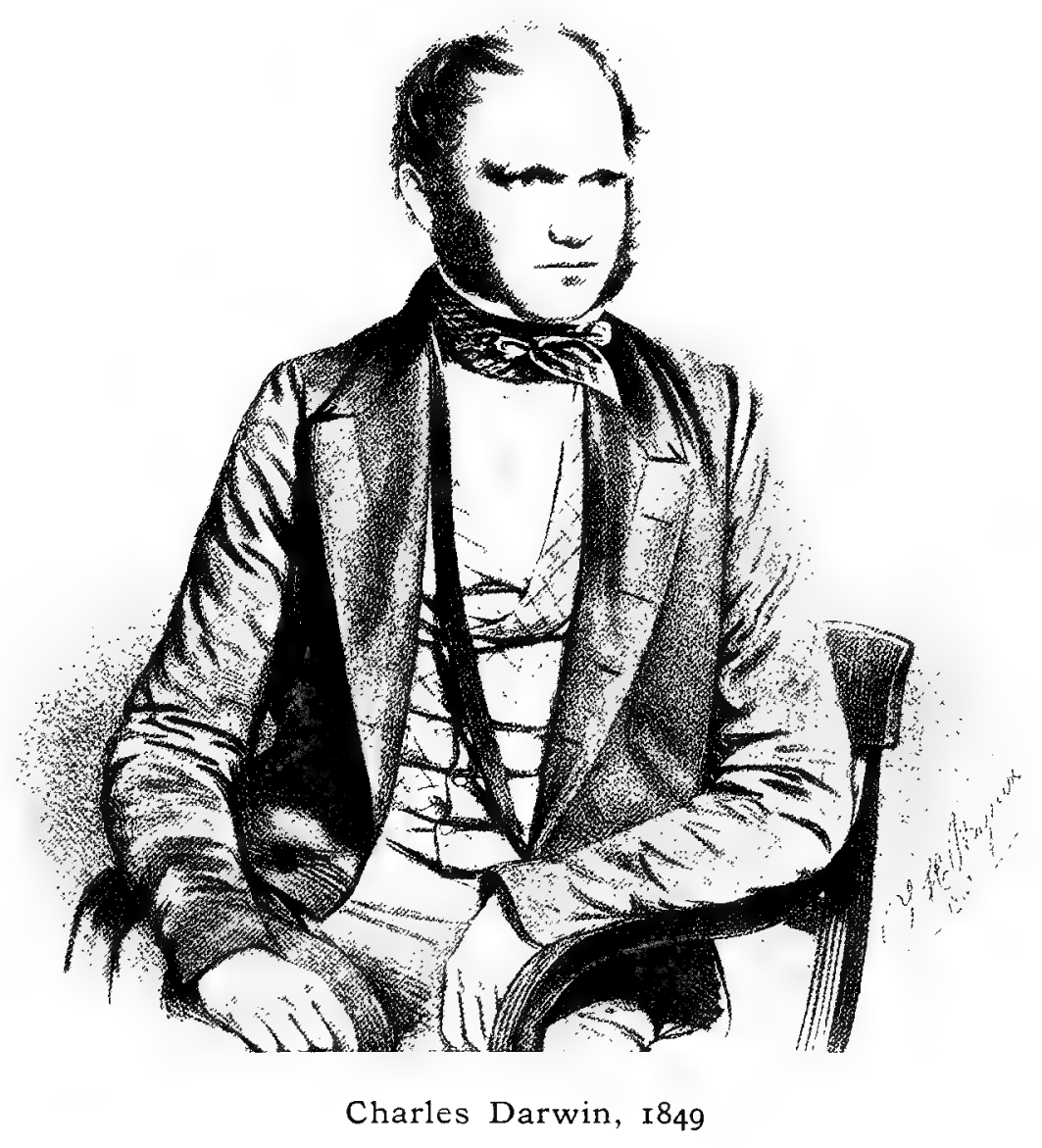



Plate $X$

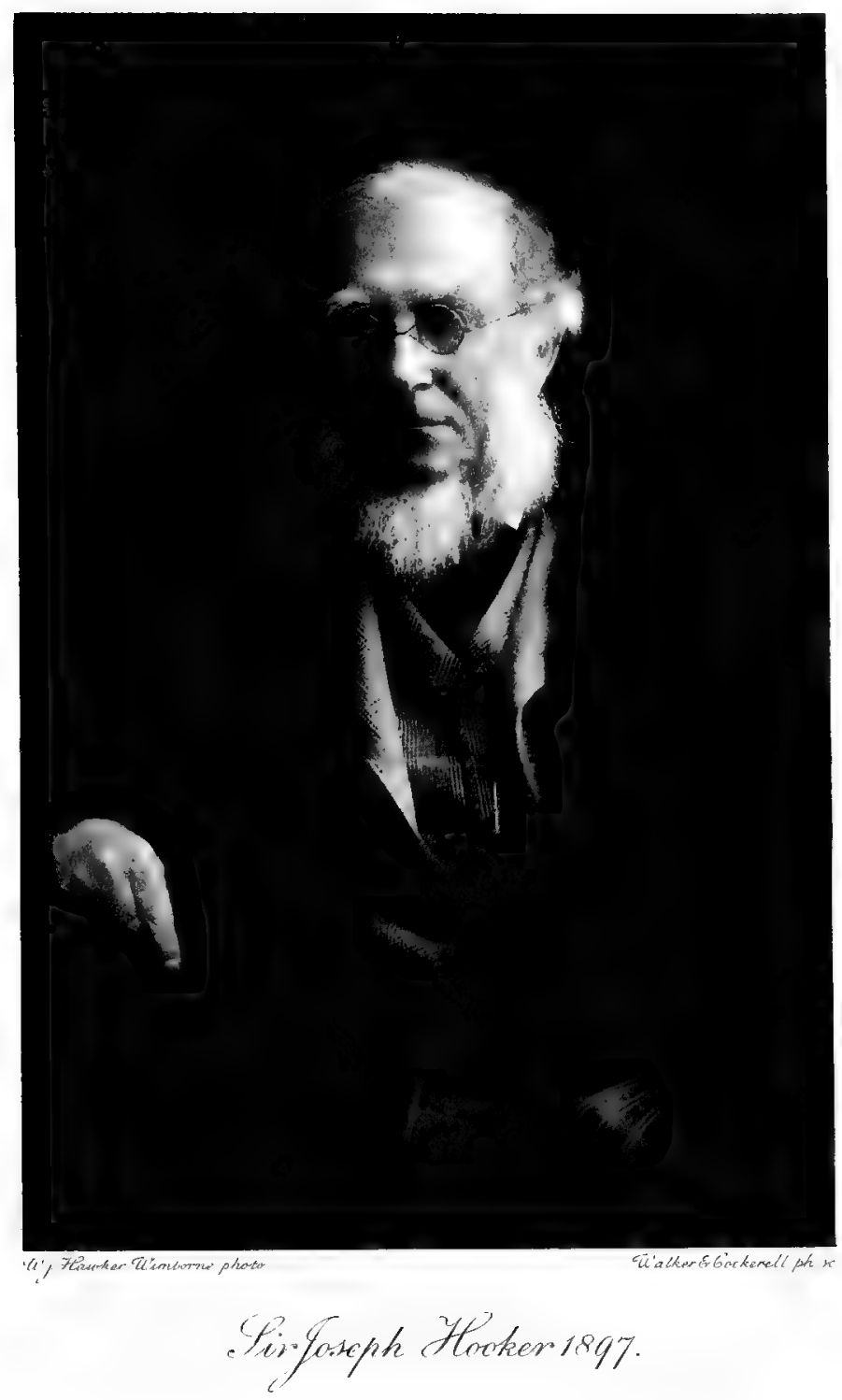



"The value of the Cirripede monograph lies not merely in the fact that it is a very admirable piece of work, and constituted a great addition to positive knowledge, but still more in the circumstance that it was a piece of critical self-discipline, the effect of which manifested itself in everything your father wrote afterwards." T. H. Huxley to F. Darwin, I887.

"One result was that he would never allow a depreciatory remark to pass unchallenged on the poorest class of scientific workers, provided that their work was honest, and good of its kind. I have always regarded it as one of the finest traits in his character,-this generous appreciation of the hod-men of science, and of their labours...and it was monographing the Barnacles that brought it about." Sir J. D. Hooker to F. Darwin, 1887.

1856 "Early in I 856 Lyell advised me to write out my views pretty fully, and I began at once to do so on a scale three or four times as extensive as that which was afterwards followed in my Origin of Species."

I858 Joint paper by Charles Darwin and Alfred Russel Wallace "On the Tendency of Species to form Varieties ; and on the perpetuation of Varieties and Species by Natural Means of Selection," communicated to the Linnean Society by Sir Charles Lyell and Sir Joseph Hooker. (Read July I.)

"I was at first very unwilling to consent [to the communication of his MS. to the Society] as I thought Mr Wallace might consider my doing so unjustifiable, for I did not then know how generous and noble was his disposition."

Nov. 24. Publication of The Origin of Species (1 250 copies).

"I never even built a castle in the air of such success as it has met with; I do not mean the sale, but the impression it has made on you (whom I have always looked at as chief judge) and Hooker and Huxley. The whole has infinitely exceeded my wildest hopes." From a letter to Lyell, I859.

"I have received your kind note and the copy; I am infinitely pleased and proud at the appearance of my child.... You are really too generous to me about the, to me, scandalously heavy corrections. Are you not acting unfairly towards yourself?" From a letter to Mr John Murray, I859.

"The most potent instrument for the extension of the realm of natural knowledge which has come into men's hands, since the publication of Newton's 'Principia,' is Darwin's 'Origin of Species.' "Huxley, 1887.

"The oldest of all philosophies, that of Evolution, was bound hand and foot and cast into utter darkness during the millennium of theological scholasticism. But Darwin poured new life-blood into the ancient frame; the bonds burst, and the revivified thought of ancient Greece has proved 
itself to be a more adequate expression of the universal order of things than any of the schemes which have been accepted by the credulity and welcomed by the superstition of seventy later generations of men." Huxley, I 887 .

Dec. 26. Publication of Huxley's celebrated review of the Origin in the Times.

"Have you seen the splendid essay and notice of my book in the Times? I cannot avoid a strong suspicion that it is by Huxley.... It will do grand service." C. Darwin to J. D. Hooker, 1859.

1860

Publication of the second edition of the Origin (3000 copies).

Publication of a Naturalist's Voyage.

June 28. Pitched battle over the Origin at the Oxford meeting of the British Association. Defeat of the Bishop of Oxford by Huxley.

"On the whole...the supporters of Mr Darwin's views in I860 were numerically extremely insignificant. There is not the slightest doubt that, if a general council of the Church scientific had been held at that time, we should have been condemned by an overwhelming majority." Huxley, I 887 .

I861 Publication of the third edition of the Origin (2000 copies).

1862 Publication of the book On the various contrivances by which Orchids are fertilised by Insects.

"Another favourite place was 'Orchis Bank,' above the quiet Cudham valley, where fly-and musk-orchids grew among the junipers, and Cephalanthera and Neottia under the beech boughs."

I864 Received the Copley Medal, the highest honour which the Royal Society can confer.

"Some old members of the Royal are quite shocked at my having the Copley."

That such a feeling existed is clear from the action of the Council in pointedly omitting from the grounds of their award the theory set forth in the Origin. That this book could within five years of its publication be valued by the Royal Society merely as a "mass of observations, etc.," is striking evidence of the slow progress of Evolution. It may perhaps be said that 1870 is the date at which the current of scientific opinion is seen to be definitely flowing in the direction of Evolution: and I880 the time by which it had reached its full volume. Mr Huxley wrote in 1880 : 
"Those who have watched the progress of science within the last ten years will bear me out to the full, when I assert that there is no field of biological inquiry in which the influence of the Origin of Species is not traceable."

It is interesting to find that of the sixty scientific societies of which Darwin was an honorary member, only 15 , or one quarter, elected him before 1870. As to the magnitude of the change in public opinion $\mathrm{Mr}$ Huxley wrote in 1887 :

"The contrast between the present condition of public opinion upon the Darwinian question; between the estimation in which Darwin's views are now held in the scientific world; between the acquiescence, or at least quiescence, of the theologians of the self-respecting order at the present day and the outburst of antagonism on all sides in $1858-9$, when the new theory respecting the origin of species first became known to the older generation to which I belong, is so startling that, except for documentary evidence, I should be sometimes inclined to think my memories dreams."

Read a paper before the Linnean Society "On the Movements and Habits of Climbing plants." (Published as a book in I875.)

1866 cation.

Publication of the fourth edition of the Origin (1 250 copies).

Received the Prussian Order "Pour le Mérite."

Publication of the Variation of Animals and Plants under Domesti-

"About my book I will give you [Sir Joseph Hooker] a bit of advice. Skip the whole of Vol. I., except the last chapter (and that need only be skimmed) and skip largely in the 2 nd volume; and then you will say it is a very good book."

1869

Publication of the fifth edition of the Origin.

Publication of The Descent of Man.

"Although in the Origin of Species the derivation of any particular species is never discussed, yet I thought it best, in order that no honourable man should accuse me of concealing my views, to add that by the work in question "light would be thrown on the origin of man and his history."

"Darwin's work in regard to the descent of man has not been surpassed; the more we immerse ourselves in the study of the structural relationships between apes and man, the more is our path illumined by the clear light radiating from him, and through his calm and deliberate investigation, based on a mass of material in the accumulation of which he has 
never had an equal. Darwin's fame will be bound up for all time with the unprejudiced investigation of the question of all questions, the descent of the human race." G. Schwalbe in Darwin and Modern Science.

I872 Publication of the sixth edition of the Origin.

Publication of The Expression of the Emotions in Man and Animals.

1874

Publication of the second edition of The Descent of Man.

Publication of the second edition of The Structure and Distributzon of Coral Reefs.

I875 Publication of Insectivorous Plants.

"My book on 'Insectivorous Plants' was published in July I875-that is sixteen years after my first observations. The delay in this case, as with all my other books, has been a great advantage to me; for a man after a long interval can criticise his own work, almost as well as if it were that of another person."

Publication of the second edition of Variation of Animals and Plants.

Publication of The Movements and Habits of Climbing Plants as a separate book.

1876 Wrote Autobiographical Sketch (Life and Letters, Vol. I. Chap. II.).

Publication of The Effects of Cross and Self-fertilisation.

"It is remarkable that this book, the result of eleven years of experimental work, owed its origin to a chance observation. My father had raised two beds of Linaria vulgaris-one set being the offspring of crossand the other of self-fertilisation. These plants were grown for the sake of some observations on inheritance, and not with any view to cross-breeding, and he was astonished to observe that the offspring of self-fertilisation were clearly less vigorous than the others." Francis Darwin, 1887.

I877 Publication of The Different Forms of Flowers on Plants of the same species.

"I do not suppose that I shall publish any more books.... I cannot endure being idle, but heaven knows whether I am capable of any more good work."

"It may be that eventually many things will be viewed in a different light, but Darwin's investigations will always form the foundation of Floral Biology on which the future may continue to build." K. Goebel in Darwin and Modern Science.

I879 Publication of his biographical sketch of Erasmus Darwin as an introduction to E. Krause's Essay, 1882. 
1880

Publication of The Power of Movement in Plants.

"Whether this masterly conception of the unity of what has hitherto seemed a chaos of unrelated phenomena will be sustained, time alone will show. But no one can doubt the importance of what $\mathrm{Mr}$ Darwin has done, in showing that for the future the phenomena of plant movement can and indeed must be studied from a single point of view." Sir William Thiselton-Dyer, 1882. beings."

"It has always pleased me to exalt plants in the scale of organised

188I Publication of The Formation of Vegetable Mould, through the Action of Worms.

1882 Charles Darwin died at Down, April I9, and was buried in Westminster Abbey, April 26, in the north aisle of the Nave a few feet from the grave of Sir Isaac Newton.

"As for myself, I believe that I have acted rightly in steadily following and devoting my life to Science. I feel no remorse from having committed any great $\sin$, but have often and often regretted that I have not done more direct good to my fellow creatures."

In I 885, Mr Huxley, referring to "the manifestation of public feeling not only in these realms, but throughout the civilised world," called forth by the death of Charles Darwin, said:- "The causes of this deep and wide outburst of emotion are not far to seek. We had lost one of these rare ministers and interpreters of Nature whose names mark epochs in the advance of natural knowledge. For, whatever be the ultimate verdict of posterity upon this or that opinion which $\mathrm{Mr}$ Darwin has propounded; whatever adumbrations or anticipations of his doctrines may be found in the writings of his predecessors; the broad fact remains that, since the publication and by reason of the publication, of the Origin of Species the fundamental conceptions and the aims of the students of living Nature have been completely changed." 


\section{Cambrioge}

PRINTED BY JOHN CLAY, M.A.

AT THE UNIVERSITY PRESS. 



35
3

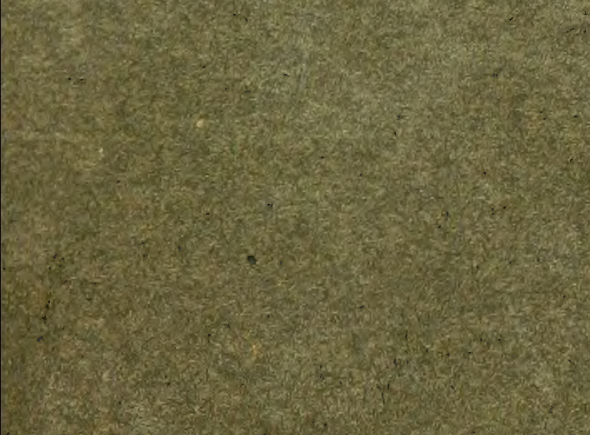

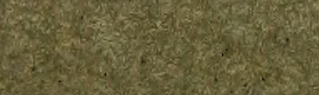
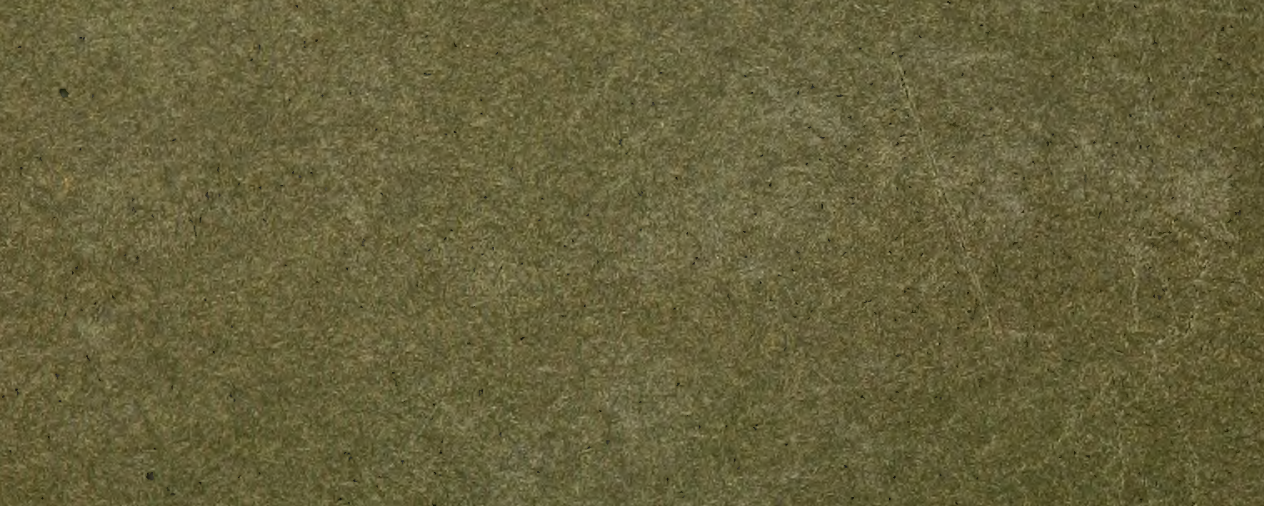

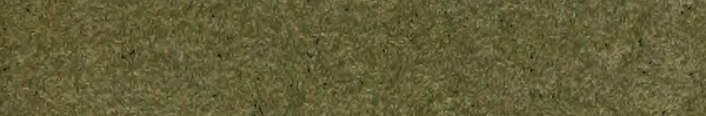

1.

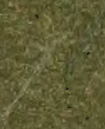

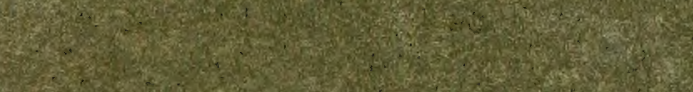

